Michał Serdyński

(Poznań)

\title{
Domowe archiwum - przykładowa budowa i okres przechowywania dokumentów oraz rachunków
}

Wiele osób gromadzi w swoich mieszkaniach różnego rodzaju dokumentację, której okres przechowywania jest różny, a jej przyrost może zacząć przeszkadzać. Stosy papierów zalegające w szafach czy szufladach zajmują miejsce, które mogłoby zostać zagospodarowane chociażby na przyszłą dokumentację. Co zatem zrobić, aby uporządkować swoje domowe archiwum? Poniżej zamieszczono kilka prostych rad.

Przede wszystkim - na początku - powinniśmy posiadaną dokumentację odpowiednio posegregować. Nie ma tu określonego klucza, gdyż tylko my sami wiemy, jak nasze dokumenty można sklasyfikować (np.: osobno rachunki za gaz, wodę, prąd, dokumenty bankowe bankowe itd.). Warto jednak pamiętać, aby w pogrupowanych zespołach zastosować układ chronologiczny tak, żeby dokument wcześniejszy znajdował się na wierzchu stosu. W trakcie porządkowania dobrze jest usunąć metalowe zszywki czy spinacze. Pozostawienie ich przy dokumentach może w dłuższej perspektywie czasu negatywnie wpłynąć na stan zachowania danego materiału. Odpowiednio posegregowaną dokumentację należy następnie stosownie zabezpieczyć. W sklepach papierniczych oraz z materiałami biurowymi można przebierać w różnego rodzaju ofertach, które pozwolą nam na prawidłowe uporządkowanie materiałów. Najpopularniejszą formą do przechowywania akt w domu są segregatory i foliowe koszulki. Można skorzystać także z gotowych teczek z zakładkami lub kieszeniami. Takie rozwiązania uchronią dokumenty przed kurzem bądź innymi zanieczyszczeniami. Warto pamiętać również o tym, ażeby przechowywane materiały trzymać - $\mathrm{w}$ miarę możliwości - $\mathrm{z}$ dala od źródeł światła czy wody, a zarazem zapewnić dostateczną ochronę na wypadek pożaru. Najważniejsze dokumenty z całego zasobu można dodatkowo zala- 
minować. Zaleca się przechowywanie ich $\mathrm{w}$ innym niż pozostałe dokumenty miejscu. Wdrożenie kilku powyższych wskazówek zapewni nie tylko porządek, ale i zabezpieczy w pewien sposób rodzinne materiały. Przyjrzyjmy się teraz niektórym dokumentom, które przechowujemy $\mathrm{w}$ domowych archiwach. Czy znany jest nam okres ich przechowywania?

Co roku na podatnikach ciąży obowiązek złożenia zeznań tzw. PIT, w których potwierdzają oni wysokość ubiegłorocznych dochodów. Podatnicy mają jednak problemy z poprawnym zinterpretowaniem przepisów, dotyczących długości przechowywania dokumentów potwierdzających stan przychodów, który przedstawili w swoich zeznaniach. W mediach i prasie kilkukrotnie już przypominano, że okres przechowywania takich dokumentów wynosi pięć lat, lecz jest on często błędnie interpretowany. Prawo regulujące powyższą kwestie zostało zawarte $w$ Ordynacji Podatkowej ${ }^{1} \mathrm{w}$ art. 70., par. 1.: "Zobowiązanie podatkowe przedawnia się z upływem 5 lat, licząc od końca roku kalendarzowego, w którym upłynął termin płatności podatku". Zgodnie z tym zapisem, rozliczając się z fiskusem w danym roku kalendarzowym do 30 kwietnia (za rok poprzedni), termin pięciu lat należy zacząć liczyć od roku następnego, w którym złożyliśmy zeznanie za poprzedni rok. Oto prosty przykład:

2013 - rok, który chcemy przedstawić w zeznaniu podatkowym,

2014 - rok aktualny, do 30 kwietnia należało złożyć zeznanie,

2015 - rok, od którego zacznie obowiązywać pięcioletni okres zachowania dokumentów,

2019 - z końcem roku dokumentację, na podstawie której rozliczaliśmy się z Urzędem Skarbowym za rok 2012, będzie można wybrakować.

W tym miejscu warto nadmienić, że w Polsce od kilku lat podatnicy, którzy rozliczają się drogą elektroniczną przez taki sam okres powinni zachować Urzędowe Poświadczenie Odbioru (UPO). Obecne prawo pozostawia w tej kwestii możliwość przechowywania UPO zarówno w formie papierowej, jak też na nośnikach komputerowych.

Inną grupą pilnie strzeżonych przez nas dokumentów i kwitów są materiały związane z umową sprzedaży. Mowa tu nie tylko o rachunkach za: wodę, prąd, gaz, Internet, telefon komórkowy itd., lecz także o tych związanych choćby np. ze sprzedażą pojazdu osobowego. Kwestie te rozstrzyga Kodeks Cywilny², a dokładniej art. 118.: „dla roszczeń o świadczenia okresowe oraz roszczeń związanych z prowadzeniem działalności gospodarczej trzy lata". Musimy jednak pamiętać, że w tym przypadku - kupno auta łączy się z podatkiem, a w związku z tym kupującego obowiązują tu także przepisy z ordynacji podatkowej. Reasumując, rachunki, a dokładniej świad-

\footnotetext{
${ }^{1}$ Dz. U. 1997, nr 137, poz. 926 ze zm.

2 Dz. U. 1964, nr 16, poz. 93 ze zm.
} 
czenia okresowe ${ }^{3}$ powinny być przechowywane przez trzy lata od momentu uregulowania płatności. Oczywiście, potwierdza do dokument, który zachowujemy przez ten okres.

Teoretycznie przez taki sam czas winno przechowywać się dokumenty związane z odprowadzaniem podatku od gruntu czy budynku mieszkalnego. Tu także mamy do czynienia z okresową płatnością na rzecz gminy bądź miasta. Art. 6., pkt 7. ustawy o podatkach i opłatach lokalnych ${ }^{4}$ precyzuje dokładne terminy opłat kwartalnych do 15. dnia określonego miesiąca za dany okres. W tym przypadku dokument potwierdzający wpłatę przechowujemy przez trzy lata od dnia ostatniego miesiąca, którego za dany okres dokonaliśmy opłaty. Jeżeli należności dokonamy po terminie, liczy się ona od daty wpłaty.

Wszelkiego rodzaju gwarancje reklamowane są z dokumentem potwierdzającym dowód zakupu danego przedmiotu. W większości przypadków potwierdzenie zakupu to paragon fiskalny, który po pewnym czasie może wyblaknąć, ponieważ do jego wydruku stosuje się drukarki termiczne, które "wypalają" cyfry, litery i znaki na papierze. Paragony powinny być przechowywane $\mathrm{w}$ ciemnym miejscu, a w dodatku nie powinno się do nich zbyt często zaglądać 5 . Warto zatem zrobić skany lub kopie tych paragonów, które dają nam możliwość ewentualnej gwarancji na towar zakupiony powyżej dwóch lat ${ }^{6}$. Jeżeli zakupu dokonywaliśmy drogą elektroniczną (Internet) i otrzymaliśmy taki paragon, powinniśmy pamiętać, że nie jest on jedynym dowodem zakupu. Potwierdzenie nabycia danego przedmiotu stanowi wyciąg z danej transakcji, który może zastąpić paragon.

Niewątpliwie ważną dokumentacją $\mathrm{w}$ naszych aktach są wszelkiego rodzaju: umowy o pracę, świadectwa pracy, świadectwa ukończenia szkoły, dyplom ukończenia studiów, akty urodzenia czy zawarcia związku małżeńskiego. Żadne przepisy nie narzucą nam długości przechowywania tychże dokumentów, lecz warto zachować je na zawsze. Pozbycie się świadectw pracy w sytuacji, gdy były pracodawca już nie istnieje, sprawi, że nie będziemy mogli uzyskać ewentualnej kopii. Poza tym za wydanie m.in. duplikatu dyplomu ukończenia studiów czy aktu urodzenia dziś ponosi się dodatkowe opłaty. Problemem może być również miejsce naszego aktualnego zamieszkania, różne od miejsca, w którym się urodziliśmy bądź studiowaliśmy. Może to wiązać się z kolejnymi kosztami - przejazdu, a także niekiedy oczekiwaniem na

\footnotetext{
${ }^{3}$ Raty kredytu nie są świadczeniami okresowymi, gdyż jest to forma świadczenia jednorazowego, które zostało rozłożone na raty. Ustalono kwotę ogólną.

${ }^{4}$ Dz. U. 1991, nr 232, poz. 31 ze zm.

${ }^{5}$ Negatywnie na ich jakość wpływa nie tylko światło, ale i wszelki ruch na warstwie, na której zostały wypalone.

${ }^{6}$ Okres ważności może być krótszy lub dłuższy, w zależności od okresu udzielonej gwarancji przez producenta nabytego przedmiotu.
} 
wydanie kopii, gdyż nie każdy urząd albo szkoła wyższa będzie w stanie wystawić żądany dokument od ręki. Wieczystym przechowywaniem powinniśmy objąć także dokumenty, takie jak: akty własności (mieszkań czy gruntów), przydziału mieszkania spółdzielczego, umów najmu, aktów darowizn, umów o rozdzielność majątkową, a co za tym idzie - także orzeczeń o rozwodzie. Pamiętajmy o dokumentacji medycznej (w granicach rozsądku ${ }^{7}$ ) - na pewno warto zachować informacje o grupie krwi czy chorobach przewlekłych.

Dokumenty bankowe stanowią kolejny ważny zespół w domowych aktach. Zacznijmy od spłaty rat kredytowych. Kwity potwierdzające uregulowania z tytułu zaciągniętych pożyczek należy przechowywać do momentu spłaty zadłużenia. Wówczas bank czy inna instytucja udzielająca kredytu pieniężnego powinna wystawić zaświadczenie, że dług względem pożyczkodawcy jest uregulowany. Przywołując ponownie Kodeks Cywilny, przytoczymy teraz początek art. 118., który wcześniej skróciliśmy: „Jeżeli przepis szczególny nie stanowi inaczej, termin przedawnienia wynosi lat dziesięć". Zgodnie z literą prawa, dokument wydany np. przez bank o spłacie zadłużenia powinniśmy przechowywać przez dziesięć lat od chwili jego otrzymania. Warto w tym miejscu nadmienić, że $\mathrm{w}$ przypadku kredytów hipotecznych należy gromadzić także wszelką dokumentację wydatków poniesionych na remonty, gdyż tylko w ten sposób będziemy w stanie udowodnić wzrost wartości nieruchomości. Potwierdzenia wykonania przelewów, wpłat na konto, należy zachować do czasu sprawdzenia stanu faktycznego. Jeżeli mamy dostęp do komputera i Internetu, a umowa z bankiem przewiduje możliwość śledzenia akcji bankowych na koncie, możemy to sprawdzić elektronicznie. Jeżeli nie mamy takiej opcji, lepiej zaczekać na miesięczne zestawienie wyciągu z konta.

Bardzo ważnymi dokumentami są wszelkiego rodzaju polisy ubezpieczeniowe, testamenty oraz dokumenty prawne nadające lub zmieniające prawo. Dobrze, aby taką dokumentację trzymać osobno i w bezpiecznym miejscu przez całe życie. Kierowcy aut powinni także odpowiednio zabezpieczyć swoje umowy OC, gdyż tylko na tej podstawie niekiedy dochodzi do obliczenia przysługujących zniżek za bezszkodową jazdę. Wracając jeszcze na moment do kwestii mieszkaniowych, warto zapamiętać, że umowy dotyczące ubezpieczenia mieszkania przechowywane powinny być przez trzy lata, mimo iż same polisy ważne są rok. Wynika to z umowy sprzedaży - patrz początek artykułu - przez co potwierdzamy opłacenie składki. Nieco inaczej wygląda sprawa w przypadku np. umów na wykonanie prac remontowych bądź umów z innych fachowców. Wiele źródeł wskazuje, że takie dokumenty należy zachować do roku od daty zakończenia robót zawartej w umowie

${ }^{7}$ Przykład. Wyniki badań krwi zrobionych w wieku dwudziestu lat nie będą przydatne po upływie kolejnych dwudziestu, chyba że mamy do czynienia z chorobą przewlekłą lub lekarz zaleci ich zachowanie. 
albo - jeżeli prace przedłużają się - od dnia ich zakończenia. Niestety, autorowi nie udało się ustalić źródła przyjętego czasu.

Emerytura. Dokumenty niezbędne do wyliczenia kwoty należnej emerytury powinien posiadać Zakład Ubezpieczeń Społecznych (ZUS), lecz z tym bywa różnie. Trzeba zatem gromadzić wszystkie te dokumenty, które pozwolą na ustalenie kapitału początkowego oraz wartości składek (najpopularniejsze, tzw. druki RMUA). Akta osobowe pracodawcy mają obowiązek przechowywać przez pięćdziesiąt lat ${ }^{8}$ od dnia zakończenia przez ubezpieczonego pracy u danego płatnika ${ }^{9}$. Co jednak zrobić, gdy firma pracodawcy została zlikwidowana lub przekształcona, a nie zachowaliśmy odpowiednich dokumentów? Wówczas należy zgłosić się do ZUS-u, który ma spis archiwów z dokumentami zlikwidowanych firm ${ }^{10}$.

Na koniec warto jeszcze wspomnieć o metodzie brakowania dokumentów, których jesteśmy pewni, że możemy się pozbyć. Wszelkie dokumenty, które mogą zawierać dane poufne bądź wrażliwe, na których podano m.in.: dane osobowe, numery kont bankowych, pisma urzędowe nie powinny trafić od razu do kosza. Mniej bezpieczną dla środowiska metodą ich zniszczenia jest spalenie, ale za to możemy mieć pewność, że dokumentacja ta nie trafi $w$ niepowołane ręce. $W$ innym przypadku dokumenty można zniszczyć w niszczarce, podrzeć lub też po złożeniu poprzecinać na kilka części. Jest to zapewne powszechny sposób pozbywania się zbędnych dokumentów, lecz nigdy nie da stuprocentowej pewności, czy aby nasze dane nie trafią $\mathrm{w}$ niepowołane ręce.

W 2013 r. archiwa państwowe i Program I Polskiego Radia zorganizowały wydarzenie pt. Zostań rodzinnym archiwista! którego celem było zachęcenie osób do tworzenia archiwów rodzinnych. Od tamtej pory powstało wiele materiałów promujących idee archiwów rodzinnych. Jedną z takich inicjatyw której pomysłodawcą była Naczelna Dyrekcja Archiwów Państwowych - było stworzenie punktów konsultacyjnych we wszystkich archiwach państwowych w Polsce. W każdej placówce odpowiednie osoby służą poradą, m.in. jak tworzyć i dbać o archiwum rodzinne. Więcej informacji o archiwach rodzinnych można znaleźć pod adresem www.archiwa.gov.pl w zakładce o tej samej nazwie ${ }^{11}$.

${ }^{8}$ Ustawa o narodowym zasobie archiwalnym i archiwach Dz. U. 1983, nr 38, poz. 173 z późniejszymi zm., art. 51.u, pkt 1.

${ }^{9}$ Ustawa o emerytach i rentach z Funduszu Ubezpieczeń Społecznych Dz. U. 2009, nr 153, poz. 1227 z późniejszymi zm.

${ }^{10}$ Data wersji bazy danych dostępnej w Internecie pochodzi z 11 kwietnia 2014 r. Autor w korespondencji elektronicznej (e-mail) z Centrum Obsługi Telefonicznej ZUS ustalił, iż jest to aktualna wersja bazy. Baza dostępna pod adresem: http://www.zus.pl/default.asp?p=4\& id=582 (dostęp: 9 września 2014 r.).

11 Zakładka dostępna w prawym menu (dostęp: 1 kwietnia 2015 r.). 
Michał Serdyński

\title{
Domowe archiwum - przykładowa budowa i okres przechowywania dokumentów oraz rachunków
}

\begin{abstract}
Streszczenie
Autor w artykule dotyczącym domowego archiwum skupia się przede wszystkim na okresie przechowywania pewnych dokumentów i rachunków, które najczęściej pojawiają się w każdym gospodarstwie domowym. Są to m.in.: dokumenty dotyczące rocznych zeznań podatkowych czy te związane z edukacją i późniejszym zatrudnieniem. Ponadto zaproponowano przykładową i prostą budowę takiego archiwum. Artykuł powstał z inspiracji wydarzenia Zostań rodzinnym archiwista, które zorganizowano trzy lata temu z inicjatywy archiwów państwowych, a promowane było w rozgłośni Programu I Polskiego Radia.
\end{abstract}

\section{A family archive - how to start one and how long to keep documents and bills}

\begin{abstract}
In an article concerning a family archive, the author focuses primarily on how long certain documents and bills, which are most frequently used in every household, are kept. These include tax return forms or documents related to education or employment. Furthermore an example of how to build a simple archive is presented. The article was inspired by the event titled Become your family's archivist, which was organized three years ago upon the initiative of the national archives and promoted in the Polish Radio Program 1.
\end{abstract}

